\title{
Factors that Govern the Sensitivity of Oat Seed to X-rays ${ }^{1}$
}

\author{
C. L. González-Molina ${ }^{2}$
}

\section{INTRODUCTION}

The sensitivity of crop plant seed to high dosages of X-rays varies with many factors, e.g., seed size, crop variety, moisture content, etc. Sensitivity of seed to X-ray treatment is usually measured by loss of seed viability or a reduction in the vigor of $\mathrm{X}_{1}$ seedlings.

Caldecott $(1)^{3}$ found a decrease in the sensitivity of barley seed when moisture content was raised from 4 to 8 percent, but there was little change over the range from 8 to 16 percent. Abrams (2) reported that oat seed containing 20 percent of moisture, and treated with $30,000 \mathrm{r}$ of X-ray, produced a lower germination percentage and seedling vigor than seed treated with a 40,000-r dosage at 14 percent of moisture. He also concluded that oat varieties produced under similar environmental conditions differed in their sensitivity to X-rays.

Fröier and Gustafsson (S) treated Kolben and Velvet wheat varieties with 10,000 and $20,000 \mathrm{r}$ and found large seed were affected less by X-rays than were small ones. The same authors, working with hulled and dehulled barley, and oat seed at dosages of 10,000 and 20,000 r of X-rays, discovered that the hull covering caused the seed to be less susceptible to radiation effects.

\section{OBJECTIVE}

The purpose of this study was to determine the relationship between certain physical characters of oat seed and their X-ray sensitivity, which, in turn, might elucidate varietal sensitivity differences.

The specific factors investigated were:

1. The effect of a hull covering over the oat caryopsis upon damage from $\mathrm{X}$-rays.

1 Thesis submitted to the Graduate Faculty of the Iowa State College, Ames, Iowa, in partial fulfillment of the requirements for the degree of Master of Science, August 1957.

2 Research Assistant in Agronomy, Agricultural Experiment Station, University of Puerto Rico, Río Piedras, P.R. Appreciation is expressed to K. J. Frey for guidance throughout the course of this study; to J. W. Gowen and J. Stadler for radiating the experimental materials; to P. G. Homeyer and T. W. Hormer for suggestions on the statistical treatment of the data; and to L. Everson who made the plant-germinator facilities available. All are on the staff of the Iowa State College, Ames, Iowa.

a Italic numbers in parentheses refer to Literature cited p. 211. 
2. The relative sensitivity of large and small seed of the same oat variety to $\mathrm{X}$-rays.

3. The relative damage done to the radicals and plumules from treated seed.

\section{MATERIALS AND METHODS}

For ease of presentation the different experiments will be referred to by numbers throughout this paper. In experiment I, three oat varieties, Mo. 0-205, Simcoe, and Bonham, produced under the same environmental conditions, were used to study the relationship between the hull covering and X-ray sensitivity of seed. To eliminate any confusing effects due to differential seed weights between varieties, seed of equal size were selected from each variety. The seed weights for both hulled and dehulled samples are given in table 1 . The dehulling was done by hand.

TABLE 1.-Weights (grams) of 1,500 of hulled and 1,500 dehulled seed of 3 oat varieties used

\begin{tabular}{c|c|c}
\hline Variety & Hulled-seed weight & Dehulled-seed weight \\
\hline Mo. 0-205 & 45.4 & - \\
Simcoe & 45.5 & 33.5 \\
& 45.4 & - \\
Bonham & 45.6 & 34.0 \\
& 45.5 & - \\
& 45.6 & 33.2 \\
\hline
\end{tabular}

The seed were adjusted to moisture percentages of 13.8 and 20.2 by holding them for 2 weeks in desiccators over a saturated sodium chloride solution and distilled water, respectively. Seed containing approximately 14 percent of moisture were treated with $40,000 \mathrm{r}$ of X-ray, while the seed of about 20-percent moisture were given a 30,000-r dosage.

The seed were radiated with a G.E. Maxitron X-ray machine operated at $250 \mathrm{kvp}$. and $30 \mathrm{ma}$. with the radiation filtered through a $0.25-\mathrm{mm}$. $\mathrm{Cu}+\mathrm{Al}$ filter. The distance from the anode to the target was $16.5 \mathrm{~cm}$. For radiation the oat seed were placed in a plastic container measuring 3 inches in diameter and divided into four triangular compartments; thus, four different seed lots could be radiated simultaneously.

Within 24 hours after being radiated the seed were planted in the greenhouse in flats containing a sterilized soil mixture of loam, peat, and sand in the ratio of $2: 1: 1$. The planting depth was 1 inch. A plot consisted of 100 seed planted in a row across a flat, and from 6 to 10 rows were sown per flat. The experimental design was a randomized block with three replications. Hulled and dehulled nonradiated seed containing approxi- 
mately 8.5 percent of moisture were included as checks for each variety. Germination percentages and seedling heights, in centimeters, were determined 21 days after planting. On the same day the seedlings were cut at the soil surface, and subsequently dried at $30^{\circ} \mathrm{C}$. and weighed. Dry weights were adjusted to weight per 100 seedlings, in grams.

The second factor investigated was the relationship between seed and germ size and X-ray sensitivity. Removal of the germs from oat seed proved to be difficult, but a preliminary test of treating the oat seed in solutions of $\mathrm{H}_{2} \mathrm{SO}_{4}(0.4768 \mathrm{~N})$ and water at $68^{\circ} \mathrm{C}$. for varying intervals, showed the most satisfactory treatment was at a concentration of 1 part $\mathrm{H}_{2} \mathrm{SO}_{4}$ to 25 parts of water exposed in the oven for 1 hour. The germ and endosperm data from large and small seed of Bonham variety are given in table 2. The exposed area of germ surface was 281 and 227 square units for large and small seed, respectively.

TABLE 2.-Weights (grams) of germ and endosperm in large and small seed of Bonham oat variety

\begin{tabular}{l|c|c}
\hline \multicolumn{1}{c|}{ Item } & Large seed & Small seed \\
\cline { 2 - 3 } Weight per 100 dehulled seed & 3.94 & 2.53 \\
Dry weight of germ & .16 & .12 \\
Dry weight of endosperm & 2.52 & 1.67 \\
Percentage of germs in seed & 6.35 & 7.19 \\
\hline
\end{tabular}

To determine whether seed size per se was responsible for differences in $\mathrm{X}$-ray sensitivity, the endosperm of the large seed in experiment II were trimmed off until the seed weights were the same as those of the small seed. All of the seed for this and subsequent experiments were dehulled before being tempered to 14-percent moisture. For this experiment the seed were treated with $25,000 \mathrm{r}$ of $\mathrm{X}$-rays. The different seed lots, large seed, trimmed and untrimmed, and small seed, each treated and untreated with X-rays, were planted and assayed in the greenhouse using the same techniques as those in experiment $\mathrm{I}$.

When the plastic container was used in radiating the seed it was improbable that all in a compartment received an equal X-ray dosage. Therefore, experiment III was conducted in which, before the radiation treatment, the seed were placed with the germ upward, alternating large, small, large, etc., in a single layer around the circumference of a circle. The center of the circle coincided with the center of the $\mathrm{X}$-ray target area so that the $\mathrm{X}$-rays were uniformly distributed over the seed. The proposed X-ray dosage for this experiment was 25,000-r units ${ }^{4}$.

1 A dosage lower than $25,000 \mathrm{r}$ was probable from the germination data. 
The radiated seed with appropriate checks were planted and the experiment assayed in the same manner as the earlier experiments.

Experiment IV, using a dosage of $35,000 \mathrm{r}$, was also conducted to compare the X-ray sensitivity of large and small seed of the Bonham variety. The radiation was carried out in the plastic container in the same manner as described previously, except that every 10 minutes during the radiation period the container was shaken to change the position of the seed, and thus give a more equal chance of uniform dosage to all.

The treated seed from this experiment were divided in two. The radiated seed in the first group were planted in the greenhouse following the technique of previous experiments. The other seed were germinated on blotters in a plant germinator under constant moisture, temperature, and light conditions. A plot consisted of $\mathbf{5 0}$ seed uniformly spaced on a blotter, and the experimental design was a randomized block with three replications. After 6 days measurements were taken on germination percentage and length of stem and center root. In addition, the stems and the center roots of five seedlings in each plot were measured daily to determine the rate of development of each.

Finally, in experiment V, large and small seed of the Bonham oat variety were treated with 30,000 and $40,000 \mathrm{r}$ of $\mathrm{X}$-ray. The seed were stuck in alternating rows of large and small on a flat cardboard surface measuring $12 \times 16 \mathrm{~cm}$. The distance from the anode to the target was $32.5 \mathrm{~cm}$., which resulted in a center portion of the target, measuring $8 \times 8 \mathrm{~cm}$., receiving a higher dosage than the surrounding area.

Therefore, the cardboard was so cut that the center portion could be removed when the seed on it had received the proper dosage. The surrounding area remained under the machine until it had received a dosage equivalent to the center portion. The radiated material was sown within 24 hours in both the greenhouse and plant propagator, using the technique described for previous experiments.

\section{EXPERIMENTAL RESULTS}

\section{HULLED VS. DEHULLED SEED}

The germination percentages, average seedling heights, and weights per 100 seedlings of three oat varieties grown in experiment I are presented in tables 3 to 5 , respectively. The pertinent mean squares from the analyses of variance of these data are given in table 6 for the two $\mathrm{X}$-ray dosages. As expected, the $\mathrm{X}$-ray treatment reduced the germination percentages of both hulled and dehulled seed materially. However, as can be noted, there was a significant interaction between varieties and hulled $v s$. dehulled seed at the 40,000-r treatment. There is no apparent explanation for the 
TABLE 3.-Germination percenlages of hulled and dehulled oat seed of 3 varieties when radialed and not radialed in experiment I

\begin{tabular}{|c|c|c|c|c|c|c|c|c|c|}
\hline \multirow{2}{*}{$\begin{array}{l}\text { Treatment and } \\
\text { condition of sced }\end{array}$} & \multicolumn{3}{|c|}{ Mo. 0-205 } & \multicolumn{3}{|c|}{ Simcoe } & \multicolumn{3}{|c|}{ Bonham } \\
\hline & $\begin{array}{c}\text { Radi- } \\
\text { ated }\end{array}$ & Non- & Check' & $\begin{array}{l}\text { Radi- } \\
\text { ated }\end{array}$ & $\begin{array}{c}\text { Non- } \\
\text { radiated }\end{array}$ & Check 1 & $\begin{array}{l}\text { Radi- } \\
\text { ated }\end{array}$ & $\begin{array}{l}\text { Non- } \\
\text { radiated }\end{array}$ & Check' \\
\hline $40,000 \times$ of $X$-ray & & & & & & & & & \\
\hline Hulled & 32.6 & 99.3 & 99.3 & 63.6 & 98.6 & 99.0 & 9.3 & 99.0 & 98.3 \\
\hline Dehulled & 3.3 & 98.6 & 99.3 & 68.3 & 97.3 & 98.0 & 39.6 & 99.0 & 99.0 \\
\hline 30,000 r of $X$-ray & & & & & & & & & \\
\hline Hulled & 20.3 & 94.0 & 99.0 & 49.0 & 75.0 & 98.6 & 54.6 & 75.3 & 98.0 \\
\hline Dehulled & 1.0 & 61.0 & -(2) & 17.6 & 52.6 & -(2) $^{(2)}$ & 4.0 & 46.6 & -(2) \\
\hline
\end{tabular}

1 Seed contained 8.5 percent of moisture.

2 No dehulled check included.

TABLE 4.-Height of seedlings (centimeters) from hulled and dehulled oat seed of $\mathrm{s}$ varieties when radiated and not radiated in experiment $I$

\begin{tabular}{|c|c|c|c|c|c|c|c|c|c|}
\hline \multirow{2}{*}{$\begin{array}{l}\text { Treatment and } \\
\text { condition of seed }\end{array}$} & \multicolumn{3}{|c|}{ Mo. 0-205 } & \multicolumn{3}{|c|}{ Simcoe } & \multicolumn{3}{|c|}{ Bonham } \\
\hline & $\begin{array}{l}\text { Radi- } \\
\text { ated }\end{array}$ & $\begin{array}{c}\text { Non- } \\
\text { radiated }\end{array}$ & Check 1 & $\begin{array}{l}\text { Radi- } \\
\text { ated }\end{array}$ & $\left|\begin{array}{c}\text { Non- } \\
\text { radiated }\end{array}\right|$ & Check! & $\begin{array}{l}\text { Radi- } \\
\text { rated }\end{array}$ & $\begin{array}{l}\text { Non- } \\
\text { radiated }\end{array}$ & Check 1 \\
\hline 40,000 r of X-ray & & & & & & & & & \\
\hline Hulled & 9.2 & 28.9 & 27.2 & 0.1 & 30.0 & 30.4 & 3.7 & 26.1 & 26.0 \\
\hline Dehulled & 2.4 & 28.0 & 27.0 & 6.2 & 28.7 & 28.0 & 7.0 & 25.9 & 26.1 \\
\hline 30,000 r of $X$-ray & & & & & & & & & \\
\hline Hulled & 8.2 & 25.1 & 26.6 & 7.0 & 28.6 & 29.6 & 5.3 & 25.5 & 26.6 \\
\hline Dehulled & 1.0 & 26.9 & -(2) $^{(2)}$ & 8.5 & 28.0 & -(2) & 2.4 & 25.2 & -(2) \\
\hline
\end{tabular}

1 Seed contained 8.5 percent of moisture.

2 No dehulled check included.

TABLE 5.-Dry weight per 100 seedlings (grams) from hulled and dehulled oat seed of 3 varielies when radialed and not radiated in experiment $I$

\begin{tabular}{|c|c|c|c|c|c|c|c|c|c|}
\hline \multirow{2}{*}{$\begin{array}{l}\text { Treatment and } \\
\text { condition of seed }\end{array}$} & \multicolumn{3}{|c|}{ Mo. 0-205 } & \multicolumn{3}{|c|}{ Simcoe } & \multicolumn{3}{|c|}{ Bonham } \\
\hline & $\begin{array}{l}\text { Radi- } \\
\text { ated }\end{array}$ & $\left|\begin{array}{c}\text { Non- } \\
\text { radiated }\end{array}\right|$ & Check' & $\begin{array}{l}\text { Radi- } \\
\text { ated }\end{array}$ & $\begin{array}{c}\text { Non- } \\
\text { radiated }\end{array}$ & Check 1 & $\begin{array}{c}\text { Radi- } \\
\text { ated }\end{array}$ & $\begin{array}{l}\text { Non- } \\
\text { radiated }\end{array}$ & Check' \\
\hline 40,000 r of X-ray & & & & & & & & & \\
\hline Hulled & 0.542 & 1.742 & 1.706 & 0.388 & 1.831 & 1.945 & 0.332 & 1.726 & 1.643 \\
\hline Dehulled & .108 & 1.769 & 1.465 & .410 & 1.577 & 1.364 & .442 & 1.613 & 1.602 \\
\hline $30,000 \mathrm{r}$ of $\mathrm{X}$-ray & & & & & & & & & \\
\hline Hulled & .412 & 1.704 & 1.574 & .916 & 1.273 & 1.660 & .381 & 1.830 & 1.720 \\
\hline Dehulled & .033 & 2.057 & - (2) & .942 & 1.094 & -(2) & .368 & 1.799 & -(2) \\
\hline
\end{tabular}

1 Seed contained 8.5 percent of moisture.

2 No dehulled check included. 
TABLE 6.-Mean squares from analyses of variance of germination percentages, seedling heights, and dry weights per 100 seedlings of $S$ oat varieties from

seed radialed in experiment $I$

\begin{tabular}{l|l|l|l|l}
\hline Source of variation & Degrees of freedom & \multicolumn{3}{|c}{ Mean squares } \\
\cline { 3 - 4 } & & Germination & Seedling height & Dry weight \\
\hline
\end{tabular}

40,000 r of $X$-ray

\begin{tabular}{|c|c|c|c|c|}
\hline Treatments ขs. checks & 1 & $11,844 * *$ & $1,278.7^{* *}$ & $3.933^{* *}$ \\
\hline Within treatments & 11 & $4,182^{* *}$ & $397.8^{* *}$ & $1.476^{* *}$ \\
\hline Variety & 2 & $1,946^{* *}$ & $24.0^{* *}$ & .008 \\
\hline Hulled vs. dehulled & 1 & 3 & $17.4^{*}$ & $.138 *$ \\
\hline Radiation & 1 & $35,156^{* *}$ & $4,221.1^{* *}$ & $15.748 * *$ \\
\hline $\begin{array}{l}\text { Variety } \times \text { hulled vs. de- } \\
\text { hulled }\end{array}$ & 2 & $685^{* *}$ & $22.6^{* *}$ & .045 \\
\hline Variety $\times$ radiation & 2 & $2,125^{* *}$ & 2.9 & .035 \\
\hline $\begin{array}{l}\text { Hulled vs. dehulled } \times \\
\text { radiation }\end{array}$ & 1 & 15 & 4.3 & .016 \\
\hline $\begin{array}{l}\text { Variety } \times \text { hulled vs. de- } \\
\text { hulled } \times \text { radiation }\end{array}$ & 2 & $659 * *$ & $16.8^{* *}$ & .085 \\
\hline Within checks & 5 & 0 & $8.0^{*}$ & $.122^{* *}$ \\
\hline Variety & 2 & 1 & $15.6^{* *}$ & .007 \\
\hline Hulled vs. dehulled & 1 & $\mathbf{0}$ & 3.2 & $3.372^{* *}$ \\
\hline $\begin{array}{l}\text { Variety } \times \text { hulled } v 8 . \text { de- } \\
\text { hulled }\end{array}$ & 2 & 1 & 2.9 & $.112^{*}$ \\
\hline Error & 34 & 8 & 2.6 & .033 \\
\hline
\end{tabular}

30,000 r X-ray

\begin{tabular}{|c|c|c|c|c|}
\hline Treatments vs. checks & 1 & $19,971^{* *}$ & $992.2^{* *}$ & $2.453^{* *}$ \\
\hline Among treatments & 11 & $2,637^{* *}$ & $388.4^{* *}$ & $1.375^{* *}$ \\
\hline Variety & 2 & $70^{*}$ & $40.5^{* *}$ & .007 \\
\hline Hulled vs. dehulled & 1 & $8,949 * *$ & $17.6^{*}$ & .012 \\
\hline Radiation & 1 & $16,727^{* *}$ & $4,074.7^{* *}$ & $11.242^{* *}$ \\
\hline $\begin{array}{l}\text { Variety } \times \text { hulled } v 8 . \text { de- } \\
\text { hulled }\end{array}$ & 2 & $169 * *$ & 8.8 & .004 \\
\hline Variety $\times$ radiation & 2 & $1,303^{* *}$ & 1.1 & $1.713^{* *}$ \\
\hline $\begin{array}{l}\text { Hulled vs. dehulled } \times \\
\text { radiation }\end{array}$ & 1 & $81^{*}$ & $25.7^{* *}$ & .066 \\
\hline $\begin{array}{l}\text { Variety } \times \text { hulled vs. de }- \\
\text { hulled } \times \text { radiation }\end{array}$ & 2 & $235^{* *}$ & $26.6^{* *}$ & $.183^{* *}$ \\
\hline Among checks & 2 & 1 & 9.0 & .016 \\
\hline Error & 28 & 16 & 3.1 & .028 \\
\hline
\end{tabular}

$1 *$ Denotes significance at 5 -percent level; ${ }^{* *}$ denotes significance at 1 -percent level. 
reversal in germination percentages among varieties due to the presence or absence of hulls covering the seed.

At the 30,000-r dosage the results were in line with expectation. In all three varieties the seed with a hull-covering had a higher germination percentage than those without. Apparently the tempering process of using water in the dessicator also had an effect upon the germination percentage. Nevertheless, the germination reductions due to radiation were much greater in the dehulled than in the hulled seed lots, as is shown by the highly significant interaction mean square for "hulled $v$ s. dehulled $\times$ radiation" (table 6). Data from this portion of experiment I indicate that a hull-covering over the seed has some protective effect against $\mathrm{X}$-ray damage.

Seedling heights from seed receiving the 40,000-r dosage of X-rays showed a variety $X$ radiation interaction similar to that in germination. The interaction between varieties and hulled vs. dehulled was highly significant.

With the 30,000-r treatment the heights of seedlings from dehulled seed were reduced more by radiation than were those from hulled seed in Mo. 0-205 and Bonham varieties, but not in Simcoe. This reaction is apparent in the highly significant mean square for the second-order interaction. Dehulling of the seed seemed to have a slight but consistent effect of reducing the seedling heights of nonradiated checks. The only exception was Mo. 0-205 at the 20-percent moisture level.

Another measure of seedling vigor was weight per 100 seedlings. The effects of the hulls on X-ray sensitivity as measured by weights of the seedling were not consistent. For Mo. 0-205 the seedling weights were much less for dehulled than for hulled seed under both the 30,000- and 40,000-r treatments. Simcoe seedlings were heavier from the dehulled seed in both cases, and Bonham seedlings from the dehulled seed were heavier under the 40,000-r than at the 30,000-r treatment.

There was no consistent effect of the hull-covering on the X-ray sensitivity when measured in terms of $X_{1}$ seedling vigor. In some cases the dehulling resulted in smaller seedlings after radiation and, in others, larger. In general, seedlings from nonradiated, dehulled seed were slightly, but consistently, smaller than those from seed with hulls intact. This is indicated by a highly significant mean square for "hulled $v$ s. dehulled" within checks for weights per 100 seedlings.

In general, the results of experiment I were rather inconclusive relative to the effect of a hull-covering on the X-ray sensitivity of oat seed. Dehulling oat seed per se did not decrease the germination percentage if the seed were maintained at approximately 14 percent of moisture, but at 20percent moisture the dehulled seed were reduced much more in viability 
than were seed with hull intact. Dehulling also seemed to cause a slight but consistent reduction in seedling vigor in the varieties Simcoe and Bonham.

\section{LARGE VS. SMALL SEED}

The germination percentages, seedling heights, and weights per hundred seedlings for the large- and small-seed comparisons in the greenhouse grown

TABLE 7.-Germination percentages, seedling heights, and dry weights per 100 seedlings from trimmed and untrimmed seed of Bonham oat variety when radiated and not radiated in experiment $I I$

\begin{tabular}{|c|c|c|c|c|c|c|c|c|c|}
\hline \multirow{2}{*}{ Kind and condition of seed } & \multicolumn{3}{|c|}{ Germination (percent) } & \multicolumn{3}{|c|}{$\begin{array}{l}\text { Seedling heights } \\
\text { (percent of check) }\end{array}$} & \multicolumn{3}{|c|}{$\begin{array}{l}\text { Dry weight per } 100 \\
\text { seedlings (percent of } \\
\text { check) }\end{array}$} \\
\hline & $\underset{\text { ated }}{\text { Radi- }}$ & $\begin{array}{c}\text { Non- } \\
\text { radiated }\end{array}$ & Check $^{2}$ & $\begin{array}{l}\text { Radi- } \\
\text { ated }\end{array}$ & $\begin{array}{c}\text { Non- } \\
\text { radiated }\end{array}$ & Check' & $\begin{array}{l}\text { Radi- } \\
\text { ated }\end{array}$ & \begin{tabular}{|c|} 
Non- \\
radiated
\end{tabular} \mid & Check' \\
\hline $\begin{array}{l}\text { Large seed with } \\
\text { trimmed endosperm }\end{array}$ & 71 & 85 & - & 39 & 67 & - & 15 & 29 & 一 \\
\hline $\begin{array}{l}\text { Large seed with un- } \\
\text { trimmed endosperm }\end{array}$ & 84 & 96 & 96 & 68 & 107 & 100 & 43 & 106 & 100 \\
\hline Small sced & 30 & 97 & 99 & 61 & 100 & 100 & 48 & 91 & 100 \\
\hline
\end{tabular}

1 Seed contained 8.5 percent of moisture.

TABLE 8.-Mean squares associaled with seedling heights and weights per 100 seedlings of checks from seed of Bonham oat variety in experiment II

\begin{tabular}{l|c|c|c}
\hline \multirow{2}{*}{ Source of error } & Degrees of freedom & \multicolumn{2}{|c}{ Mean squarest } \\
\cline { 3 - 4 } & & Height & $\begin{array}{c}\text { Dry weight per } \\
\text { 100 seedlings }\end{array}$ \\
\hline & 1 & $C m$. & $G m$. \\
Check vs. treatment & 1 & 73.0 & 0.901 \\
Large vs. small checks & 14 & $8.3^{*}$ & $.192^{*}$ \\
Error & 1.8 & .022 \\
\hline
\end{tabular}

$1 *$ Denotes significance at 5-percent level.

portions of experiments II, III, IV, and V are given in tables 7 to 14 . Pertinent mean squares from analyses of variance of the data from these experiments are presented in tables $9,11,13$, and 15 , respectively. In experiment II trimming endosperm from the large seed reduced their germination to 85.0 percent, a highly significant reduction. Presumably a more rapid absorption of water and distintegration of compounds in the seed caused the deterioration in seed viability. After this experience endosperm trimming was eliminated as a treatment in subsequent experiments. 
In none of the four experiments was there a significant difference in germination percentage between nonradiated large and small seed, regardless of whether the moisture content of the seed was tempered to 14.0 percent or maintained at 8.5. When the seed were radiated and planted

TABLE 9.-Mean squares from analyses of variance of germination percentages, seedling heights, and dry weights per 100 seedlings from seed of Bonham oat variety, as percentage of checks from experiment II

\begin{tabular}{|c|c|c|c|c|}
\hline \multirow{2}{*}{ Source of variation } & \multirow{2}{*}{ Degrees of freedom } & \multicolumn{3}{|c|}{ Mean squares' } \\
\hline & & Germination & Seedling height & Dry weight \\
\hline Among treatments ${ }^{2}$ & 7 & $256^{* *}$ & $19^{* *}$ & $40^{* *}$ \\
\hline Moisture level & 1 & $460^{* *}$ & $31 * *$ & $90 * *$ \\
\hline Between checks & 1 & 11 & 0 & 0 \\
\hline Cut vs. noncut & 1 & $432^{* *}$ & $37^{* *}$ & $76^{* *}$ \\
\hline Within cuttings & 1 & $280^{* *}$ & $12^{* *}$ & 3 \\
\hline Seed size & 1 & $30^{*}$ & 1 & 0 \\
\hline Radiation & 1 & $252^{* *}$ & $46^{* *}$ & $84^{* *}$ \\
\hline Seed size $X$ radiation & 1 & 19 & 0 & 3 \\
\hline Error & 14 & 4 & 1 & 2 \\
\hline
\end{tabular}

$1 *$ Denotes significance at 5 -percent level; ** denotes significance at 1 -percent level.

2 Nonorthogonal breakdown.

TABLE 10.-Germination percentages, seedling heights, and dry weights per 100 seedlings from large and small oat seed of Bonham variety when radiated and not radiated in experiment $I I I$

\begin{tabular}{c|c|c|c|c|c|c|c|c|c}
\hline \multirow{2}{*}{ Seed size } & \multicolumn{3}{|c|}{ Germination (percent) } & \multicolumn{3}{|c|}{$\begin{array}{c}\text { Seedling heights } \\
\text { (percent of check) }\end{array}$} & \multicolumn{3}{|c|}{$\begin{array}{c}\text { Dry weight per 100 } \\
\text { seedlings (percent of check) }\end{array}$} \\
\cline { 2 - 9 } & Radiated & $\begin{array}{c}\text { Non- } \\
\text { radiated }\end{array}$ & Check1 & Radiated & $\begin{array}{c}\text { Non- } \\
\text { radiated }\end{array}$ & Check1 & Radiated & $\begin{array}{c}\text { Non- } \\
\text { radiated }\end{array}$ & Check1 \\
\hline Large & 92 & 99 & 97 & 63 & 106 & 100 & 58 & 108 & 100 \\
Small & 97 & 99 & 99 & 65 & 103 & 100 & 62 & 92 & 100 \\
\hline
\end{tabular}

${ }^{1}$ Seed contained 8.5 percent of moisture.

in the greenhouse, the percentage of seedlings emerging from the soil after 21 days, referred to herein as "germination percentage", was lower for the large than for the small seed. For dosages from 25,000 to $35,000 \mathrm{r}$ this difference was small and significant in only one case, but at the 40,000-r dosage the germination percentages were 94.0 and 66.0 for the small and large seed, respectively. This difference was highly significant. These data are contrary to those of Fröier and Gustafsson (3), but it is suggested that 
TABLE 11.-Mean squares from analyses of variance of germination percentages, seedling heights, and dry weights per 100 seedlings from seed of Bonham oat variety, as percentage of the checks in experiment III

\begin{tabular}{|c|c|c|c|c|}
\hline \multirow{2}{*}{ Source of variation } & \multirow{2}{*}{ Degrees of freedom } & \multicolumn{3}{|c|}{ Mean squares' } \\
\hline & & Germination & $\begin{array}{l}\text { Seedling } \\
\text { height }\end{array}$ & Dry weight \\
\hline Treatment vs. checks & 1 & 3 & $9.6^{* *}$ & $15.6^{*}$ \\
\hline Among treatments & 3 & $39^{* *}$ & $16.3^{* *}$ & $17.2^{*}$ \\
\hline Seed size & 1 & $21^{* *}$ & .1 & 1.1 \\
\hline Radiation & 1 & $75^{* *}$ & $48.6^{* *}$ & $47.5^{* *}$ \\
\hline Seed size $X$ radiation & 1 & $21^{* *}$ & 0 & 3.2 \\
\hline Large check vs. small check & 1 & 6 & 0 & 0 \\
\hline Error & 10 & 2 & .4 & 3 \\
\hline
\end{tabular}
level.

$1 *$ Denotes significance at 5-percent level; ** denotes significance at 1-percent

TABLE 12.-Germination percentages, seedling heights, and dry weights per 100 seedlings from large and small seed of Bonham oat variety when radiated and not radiated in experiment $I V$

\begin{tabular}{c|c|c|c|c|c|c|c|c|c}
\hline \multirow{2}{*}{ Seed size } & \multicolumn{2}{|c|}{ Germination (percent) } & \multicolumn{2}{c|}{$\begin{array}{c}\text { Seedling height (percent of } \\
\text { check) }\end{array}$} & \multicolumn{2}{c}{$\begin{array}{c}\text { Dry weight per 100 } \\
\text { seedlings (percent of check) }\end{array}$} \\
\cline { 2 - 7 } & Radiated & $\begin{array}{c}\text { Non- } \\
\text { radiated }\end{array}$ & Check1 & Radiated & $\begin{array}{c}\text { Non- } \\
\text { radiated }\end{array}$ & Check1 & Radiated & $\begin{array}{c}\text { Non- } \\
\text { radiated }\end{array}$ & Check1 \\
\hline Large & 87 & 98 & 99 & 46 & 92 & 100 & 34 & 112 & 100 \\
Small & 96 & 99 & 98 & 68 & 98 & 100 & 55 & 99 & 100 \\
\hline
\end{tabular}

${ }^{1}$ Seed contained 8.5 percent of moisture.

TABLE 13.-Mean squares from analyses of variance of germination percentages, seedling heights, and dry weights per 100 seedlings from seed of Bonham oat variety as percentage of checks from greenhouse-grown portion of experiment IV

\begin{tabular}{|c|c|c|c|c|}
\hline \multirow{2}{*}{ Source of variation } & \multirow{2}{*}{ Degrees of frecdom } & \multicolumn{3}{|c|}{ Mean squares! } \\
\hline & & Germination & $\begin{array}{l}\text { Seedling } \\
\text { height }\end{array}$ & $\begin{array}{c}\text { Dry weight per } \\
100 \text { seedlings }\end{array}$ \\
\hline Checks vs. treatment & 1 & 40 & $24^{*}$ & $25^{* *}$ \\
\hline Among treatments & 3 & $87^{* *}$ & $17^{*}$ & $41^{* *}$ \\
\hline Seed size & 1 & $75^{*}$ & 5 & 1 \\
\hline Radiation & 1 & $147^{* *}$ & $45^{* *}$ & $113^{* *}$ \\
\hline Seed size $X$ radiation & 1 & 40 & 2 & g* \\
\hline Large check vs. small check & 1 & 1 & 0 & 0 \\
\hline Error & 10 & 10 & 3 & 1.4 \\
\hline
\end{tabular}

$1 *$ Denotes significance at 5 -percent level; ** denotes significance at 1 -percent level. 
their results might have been different because they used another $\mathrm{X}$-ray dosage.

When the data on seedling heights and weights per seedling were analyzed for experiments II through $\mathrm{V}$ it was found that the seedlings

TABLE 14.-Germination percentages, seedling heights, and dry weights per 100 seedlings from large and small oat seed of Bonham variety when radiated and not radiated in experiment $V$

\begin{tabular}{|c|c|c|c|c|c|c|c|c|c|}
\hline \multirow{3}{*}{ Seed size } & \multicolumn{3}{|c|}{ Germination (percent) } & \multicolumn{3}{|c|}{$\begin{array}{l}\text { Seedling heights (percent } \\
\text { of check) }\end{array}$} & \multicolumn{3}{|c|}{$\begin{array}{l}\text { Dry weight per } 100 \\
\text { seedlings (percent of check) }\end{array}$} \\
\hline & \multicolumn{2}{|c|}{ Radiated at - } & \multirow{2}{*}{$\underset{\text { radiated }}{\text { Non- }}$} & \multicolumn{2}{|c|}{ Radiated at- } & \multirow{2}{*}{$\begin{array}{l}\text { Non- } \\
\text { radiated }\end{array}$} & \multicolumn{2}{|c|}{ Radiated at- } & \multirow{2}{*}{$\begin{array}{l}\text { Non- } \\
\text { radiated }\end{array}$} \\
\hline & $30,000 \mathrm{I}$ & $40,000 \mathrm{r}$ & & $30,000 \mathrm{r}$ & $40,000 \mathrm{r}$ & & $30,000 \mathrm{r}$ & $40,000 \mathrm{r}$ & \\
\hline Large & 95 & 66 & 96 & 64 & 45 & 100 & 72 & 28 & 100 \\
\hline Small & 96 & 94 & 100 & 75 & 64 & 100 & 68 & 54 & 100 \\
\hline
\end{tabular}

TABLE 15.-Mean squares from analyses of variance of germination percentages, seedling heights, and dry weights per 100 seedlings from seed of Bonham oat variety, as percentage of checks from the greenhouse-grown portion of experiment $V$

\begin{tabular}{|c|c|c|c|c|}
\hline \multirow{2}{*}{ Source of variation } & \multirow{2}{*}{ Degrees of freedom } & \multicolumn{3}{|c|}{ Mean squares' } \\
\hline & & $\begin{array}{l}\text { Germination } \\
\text { (percent) }\end{array}$ & $\begin{array}{l}\text { Seedling height } \\
\text { (percent of } \\
\text { check) }\end{array}$ & $\begin{array}{c}\text { Dry weight } \\
\text { per seedlings } \\
\text { (percent of check) }\end{array}$ \\
\hline Among treatments & 5 & $450^{* *}$ & $14^{* *}$ & $23^{* *}$ \\
\hline Checks vs. radiation & 1 & $400^{* *}$ & $57^{* *}$ & $71^{* *}$ \\
\hline $\begin{array}{l}\text { Large check vs. small } \\
\text { check }\end{array}$ & 1 & 24 & 0 & 0 \\
\hline 30,000 r vs. $40,000 \mathrm{r}$ & 1 & $705^{* *}$ & $7^{* *}$ & $34^{* *}$ \\
\hline $\begin{array}{l}\text { Large } 30,000 \mathrm{r} \text { vs. small } \\
30,000 \mathrm{r}\end{array}$ & 1 & 1 & $2^{* *}$ & 0 \\
\hline $\begin{array}{l}\text { Large } 40,000 \mathrm{r} \text { vs. small } \\
\quad 40,000 \mathrm{r}\end{array}$ & 1 & $1,121^{* *}$ & $5^{* *}$ & $10^{* *}$ \\
\hline Error & 10 & 21 & .10 & .43 \\
\hline
\end{tabular}

$1 *$ Denotes significance at 5 -percent level; ${ }^{* *}$ denotes significance at 1 -percent level.

from nonradiated large seed were always significantly larger than those from small seed (e.g. table 8). Thus, any differences which existed between the seedlings from radiated large and small seed would undoubtedly be confounded with the initial differences between these two seed classes. To eliminate this confounding factor the seedling heights and weights per 100 seedlings of the large and small checks with 8.5 moisture were regarded as equal to 100 , and the other data were expressed as a percentage of these 
checks. All the data on seedling heights and weights per 100 seedlings in tables $7,10,12$, and 15 are expressed in this way.

In experiments II and III where the X-ray dosages were $25,000 \mathrm{r}$ or less, seedling heights and weights per 100 seedlings from radiated large and small seed were not significantly different when expressed relative to the checks. For example, the relative values for seedling heights from large and small seed were 68 and 61, respectively, in experiment II, and 63 and 65 in experiment III. Even at the 30,000-r dosage in experiment $V$ the relative values for seedling heights and weights per 100 seedlings were not materially different between large and small seed. In experiment IV, wherein the X-ray dosage was $35,000 \mathrm{r}$, the relative values for seedling vigor were significantly lower for the seedlings from large than from small seed. The relative values for plant heights were 46 and 66, respectively, and for weights per 100

TABLE 16.-Germination percentages and length of stems and center roots of plantgerminator-grown seedlings from large and small seed of Bonham oat variety when radialed and not radiated in experiment $I V$

\begin{tabular}{|c|c|c|c|c|c|c|c|c|c|}
\hline \multirow{2}{*}{ Seed size } & \multicolumn{3}{|c|}{ Germination } & \multicolumn{3}{|c|}{ Length of center root } & \multicolumn{3}{|c|}{ Length of stem } \\
\hline & Radiated & $\begin{array}{c}\text { Non- } \\
\text { radiated }\end{array}$ & Check' & Radiated & $\begin{array}{c}\text { Non- } \\
\text { radiated }\end{array}$ & Check1 & Radiated & $\begin{array}{c}\text { Non- } \\
\text { radiated }\end{array}$ & Check' \\
\hline & Percent & Percent & Percent & $\mathrm{Cm}$. & $C m$ & $\mathrm{Cm}$ & $C_{m}$ & $C m$ & $\mathrm{Cm}$. \\
\hline Large & 99 & 100 & 100 & 2.58 & 8.25 & 7.27 & 1.28 & 4.99 & 4.64 \\
\hline Small & 99 & 100 & 100 & 2.44 & 6.98 & 7.64 & 1.10 & 4.26 & 5.44 \\
\hline
\end{tabular}

1 Seed contained 8.5 percent of moisture.

seedlings 34 and 55, respectively. The results from the 40,000-r treatment in experiment $V$ were nearly identical with those from experiment IV. From these experiments it appears that the $\mathrm{X}_{1}$ seedling vigor from large seed is relatively more damaged by $\mathrm{X}$-ray treatment than that from small ones. The differences were small to nonexistent at a dosage of $25,000 \mathrm{r}$ or less, but became greater as the dosage was increased up to 40,000 r. At the highest dosage the $X_{1}$ seedlings from large seed were only about two-thirds as vigorous as those from small seed.

\section{RESULTS WITH SEED UNDER CONTROL IN PLANT GERMINATOR}

A portion of the seed in experiments IV and $V$ was sown in a plant germinator under controlled light, moisture, and temperature conditions. Data for germination percentages and length of stem and center roots for these experiments are given in tables 16 and 18. The pertinent mean squares from the analyses of variance are presented in tables 17 and 19. Radiation of the seed with $30,000,35,000$, or $40,000 \mathrm{r}$ of X-ray had no effect on their germination, either large or small. Significant differences existed be- 
TABLE 17.-Mean squares from analyses of variance of germination percentages and lengths of stems and center rools from plant-germinator-grown Bonham oat variety seedlings in experiment IV

\begin{tabular}{|c|c|c|c|c|}
\hline \multirow{2}{*}{ Source of variation } & \multirow{2}{*}{ Degrees of freedom } & \multicolumn{3}{|c|}{ Mean squares 1} \\
\hline & & Germination & $\begin{array}{l}\text { Length of } \\
\text { center roots }\end{array}$ & $\begin{array}{l}\text { Length of } \\
\text { stems }\end{array}$ \\
\hline Check vs. treatments & 1 & 1.0 & $22.88^{* *}$ & $18.18^{* *}$ \\
\hline Among treatments & 3 & 1.2 & $26.92^{* *}$ & $21.10^{* *}$ \\
\hline Seed size & 1 & - & 1.48 & .63 \\
\hline Radiation & 1 & - & $78.74^{* *}$ & $35.43^{* *}$ \\
\hline Seed size $X$ radiation & 1 & - & .09 & .23 \\
\hline Large check vs. small check & 1 & 0 & .05 & $.96^{*}$ \\
\hline Error & 10 & .5 & .35 & .15 \\
\hline
\end{tabular}

$1 *$ Denotes significance at 5 -percent level; ** denotes significance at 1-percent level.

TABLE 18.-Germination percentages and length of stems and center roots of plant-germinator-grown seedlings from large and small seed of Bonham oat variety when radiated and not radiated in experiment $V$

\begin{tabular}{|c|c|c|c|c|c|c|c|c|c|}
\hline \multirow{2}{*}{ Seed size } & \multicolumn{3}{|c|}{ Germination } & \multicolumn{3}{|c|}{ Length of center root } & \multicolumn{3}{|c|}{ Length of stem } \\
\hline & $\begin{array}{r}30,000 \mathrm{r} \\
\text { of X-ray }\end{array}$ & $\begin{array}{l}40,000 \mathrm{r} \\
\text { of X-ray }\end{array}$ & $\begin{array}{c}\text { Non- } \\
\text { radiated }\end{array}$ & $\begin{array}{l}30,000 \mathrm{r} \\
\text { of X-ray }\end{array}$ & $\begin{array}{l}40,000 \mathrm{r} \\
\text { of X-ray }\end{array}$ & $\begin{array}{l}\text { Non- } \\
\text { radiated }\end{array}$ & $\begin{array}{c}30,000 \mathrm{r} \\
\text { of X-ray }\end{array}$ & $\begin{array}{l}40,000 \mathrm{r} \\
\text { of X-ray }\end{array}$ & $\begin{array}{c}\text { Non- } \\
\text { radiated }\end{array}$ \\
\hline & Percent & Percent & Percent & $C m$. & $C_{m}$. & $C_{m}$. & $C m$. & $C_{m}$. & $C_{m}$. \\
\hline Large & 100 & 99 & 99 & 2.4 & 1.3 & 9.3 & 2.5 & 1.7 & 9.1 \\
\hline Small & 99 & 100 & 100 & 3.1 & 1.3 & 9.2 & 2.7 & 1.6 & 7.6 \\
\hline
\end{tabular}

TABLE 19.-Mean 8quares from analyses of variance of germination percentages and lengths of stems and center roots of plant-germinator-grown Bonham oat variety seedlings in experiment $V$

\begin{tabular}{|c|c|c|c|c|}
\hline \multirow{2}{*}{ Source of variation } & \multirow[b]{2}{*}{ Degrees of freedom } & \multicolumn{3}{|c|}{ Mean squares' } \\
\hline & & Germination & $\begin{array}{l}\text { Length of } \\
\text { center roots }\end{array}$ & $\begin{array}{c}\text { Length of } \\
\text { stems }\end{array}$ \\
\hline $\begin{array}{l}\text { Among treatments } \\
\text { Check vs. radiation } \\
\text { Large checks vs. small checks } \\
30,000 \mathrm{r} \text { vs. } 40,000 \mathrm{r} \\
\text { Large } 30,000 \mathrm{r} \text { vs. small } 30,000 \mathrm{r} \\
\text { Large } 40,000 \mathrm{r} \text { vs. small } 40,000 \mathrm{r} \\
\text { Error }\end{array}$ & $\begin{array}{rr} & 1 \\
& 1 \\
& 1 \\
& 1 \\
& 1 \\
10 & \end{array}$ & $\begin{array}{l}0.4 \\
0 \\
.7 \\
0 \\
.7 \\
.7 \\
.8\end{array}$ & $\begin{array}{c}43.19^{* *} \\
208.95^{* *} \\
.01 \\
6.21^{* *} \\
.76 \\
0 \\
.33\end{array}$ & $\begin{array}{c}32.05^{* *} \\
153.93^{* *} \\
3.26^{*} \\
3.00^{*} \\
.04 \\
.01 \\
.50\end{array}$ \\
\hline
\end{tabular}

$1 *$ Denotes significance at 5-percent level; ** denotes significance at 1-percent level. 
tween the stem lengths from large and small check seed in both experiments, but the root lengths did not differ in either one.

Several seedlings in each plot in experiment $V$, sown in the germinator, were measured daily for length of stem and center root. Data from these observations are given in table 20 . The center rootlet in the checks elongated faster than the stem during the first couple of days, but after that the stem

TABLE 20.-Daily length (centimeters) of stems and center roots of plant-germinator-grown Bonham oat variety seedlings in experiment $\mathrm{V}$

\begin{tabular}{|c|c|c|c|c|c|c|c|c|}
\hline \multirow{2}{*}{ Kind of seed and treatment } & \multicolumn{4}{|c|}{$\begin{array}{l}\text { Stem on indicated days } \\
\text { after planting }\end{array}$} & \multicolumn{4}{|c|}{$\begin{array}{l}\text { Center root on indicated } \\
\text { days after planting }\end{array}$} \\
\hline & 1 & 2 & 3 & 4 & 1 & 2 & 3 & 4 \\
\hline Large seed, $30,000 \mathrm{r}$ of X-rays & 0.2 & 0.6 & 1.0 & 2.5 & 0.8 & 1.4 & 2.0 & 2.4 \\
\hline Large seed, nonradiated & .5 & 1.6 & 3.0 & 9.1 & 1.3 & 2.9 & 5.4 & 9.3 \\
\hline Small seed, $30,000 \mathrm{r}$ of $\mathrm{X}$-rays & .3 & .6 & .9 & 2.5 & .7 & 1.5 & 2.2 & 3.1 \\
\hline Small seed, nonradiated & .4 & 1.3 & 2.7 & 7.6 & 1.0 & 2.9 & 5.5 & 9.2 \\
\hline Large seed, $40,000 \mathrm{r}$ of X-rays & .2 & .4 & .7 & 1.7 & .6 & 1.0 & 1.3 & 1.3 \\
\hline Small seed, $40,000 \mathrm{r}$ of $\mathrm{X}$-rays & .2 & .4 & .7 & 1.6 & .6 & 1.0 & 1.2 & 1.3 \\
\hline
\end{tabular}

TABLE 21.-Ratio of length (centimeters) of lateral to center roollets of plant-germinator-grown Bonham oat variety seedlings in experiment $V$

\begin{tabular}{l|c|c|c}
\hline \multicolumn{1}{c|}{ Kind of seed and treatment } & $\begin{array}{c}\text { Length of center } \\
\text { root }\end{array}$ & $\begin{array}{c}\text { Length of lateral } \\
\text { roots }\end{array}$ & Ratio L/C \\
\hline Large seed, 30,000 r of X-rays & 2.4 & 1.47 & 0.61 \\
Large seed, nonradiated & 9.3 & 8.99 & .97 \\
Small seed, 30,000 r of X-rays & 3.1 & 1.69 & .55 \\
Small seed, nonradiated & 9.2 & 8.90 & .97 \\
Large seed, 40,000 r of X-rays & 1.3 & .60 & .46 \\
Small seed, 40,000 r of X-rays & 1.3 & .39 & .30 \\
\hline
\end{tabular}

tended to grow faster. Radiation at either a 30,000 - or $40,000-\mathrm{r}$ dosage reduced root and stem growth to about the same relative extent. In table 21 the ratios of lateral to central root lengths are shown. In the check seedlings from both large and small seed the ratio was 0.97 , while in the radiated seedlings the ratios ranged from 0.30 to 0.61 . This indicates that the lateral roots were affected much more by radiation than was the central one.

The data from the plant germinator suggest that the reduction in germination observed in greenhouse tests does not result from seeds being killed by $\mathrm{X}$-rays, but simply from a reduction in vigor. When the seed were 
planted 1 inch deep in the soil mixture many of the $\mathrm{X}$-rayed ones were not vigorous enough to emerge from the soil.

\section{DISCUSSION}

The results reported herein show that radiated oat seed containing 14 percent of moisture were less susceptible to damage from X-ray treatment than those containing 20 percent. Tempering seed to 20 percent of moisture caused a decrease in seed viability per se. This may have been produced by an initiation of mitosis in the high-moisture seed, followed by lethality in certain seed when they were dried again.

The protection afforded seed embryos by a hull-covering varied with the moisture content of the seed and with variety. Varietal response to $\mathrm{X}$-rays could possibly be due to the characteristics of the hulls of the different varieties. Thickness of the hull or interference with moisture absorption

TABLE 22.-Ratios of relative vigor reduction of large to small Bonham oat seed caused by varying dosages of $X$-rays in experiments $I I$ to $V$

\begin{tabular}{c|c|c|c}
\hline Experiment No. & Dosage of X-ray (r) & Seedling height & $\begin{array}{c}\text { Weights per 100 } \\
\text { seedlings }\end{array}$ \\
\cline { 2 - 4 } II & 25,000 & 107 & 80 \\
III & 25,000 & 90 & 71 \\
IV & 35,000 & 66 & 64 \\
V & 30,000 & 69 & 114 \\
& 40,000 & 65 & 64 \\
\hline
\end{tabular}

into the seed could be factors where the hull influenced the X-ray sensitivity of oat seed. In this experiment dehulled seed absorbed moisture more quickly than their hulled counterparts. Under any circumstances the data from experiment I relative to the effect of hull-covering on the X-ray sensitivity of oat seed were rather inconclusive. The differential varietal reactions noted suggest that study of this factor could well be pursued further.

Since the embryo or germ of an oat seed is the portion which produces the young seedling, it might be reasoned that small seed would show less damage because the $\mathrm{X}$-ray target area is smaller. The average weights of the germs from the large and small seed of Bonham variety were 0.16 and $0.12 \mathrm{gm}$., respectively, and the germ surface areas were 281 and 227 square units, respectively. The ratios of small to large seed for weight and surface were 0.75 and 0.80 respectively. The ratios of relative damage of large to small seed measured by reductions in plant height and weights per 1 hundred seedlings are given in table 22.

The ratio of relative damage for seedling heights appears to vary with 
the dosage of X-ray. At the 25,000-r level the relative damage to both seed sizes was about the same, whereas at from 30,000 to $40,000 \mathrm{r}$ the relative damage to the $X_{1}$ seedlings from small seed was only two-thirds as great as that to those from large ones. At the lower dosage the ratio of relative damage was higher than either the germ weight or surface-area ratios and at the higher dosages it was smaller.

For weights per 100 seedlings the ratio of relative damage between $X_{1}$ seedlings from large and small seed was in line with the ratios of germ weights and surface area. At 35,000- and 40,000-r levels the seedlings from small seed showed only about two-thirds as much damage as those from large seed. For some unexplainable reason the $\mathrm{X}_{1}$ seedlings from large seed given the 30,000-r dose in experiment $\mathrm{V}$ were not damaged as much as those from small seed.

It appears that the differences in germ size between large and small oat seed do not account for all of the differential damage obtained in $X_{1}$ seedlings from radiation with high dosages of $\mathrm{X}$-rays. At least the ratios of target weights and surface areas do not correspond too closely to the ratios of relative damage. Furthermore, the latter ratios tend to vary with dosage. Perhaps one would find a closer relationship between growing-point ratios and ratios of relative damage between small and large seed. Also, the differential ratios of relative damage with different $\mathrm{X}$-ray dosages may be confounded with double hits.

A discrepancy was observed between the germination percentages of radiated seed when grown in the greenhouse and in the plant germinator. In the greenhouse the germination percentages were reduced by high X-ray dosages, while in the plant germinator even the seed lot receiving $40,000 \mathrm{r}$ germinated 99 percent. In all probability the same percentage of seed sprouted in the greenhouse soil and on the blotters in the germinator, but in the first case the seedlings had to grow through 1 inch of soil before they were classed as germinated. Any seedlings which lacked the vigor to accomplish this would be classed as from dead. In the germinator any seed which sprouted were classed as germinated. This suggests that all of the reactions observed were due to reduced vigor of the seedlings and not to seed lethality. Very likely this vigor reduction is due to the effect of X-rays upon the chromosones which, in turn, is related to cell division. This also emphasizes the fact that seedling vigor is probably the best measure of damage done by X-rays.

\section{SUMMARY}

A series of experiments was performed designed to determine the relationship between hull covering and seed and germ size to X-ray sensitivity of oat seed of three varieties: Mo. 0-205, Simcoe, and Bonham. The seed 
contained approximately 14 and 20 percent of moisture and X-ray dosages of 40,000 and $30,000 \mathrm{r}$ were used. The data indicated that:

1. Hull-coverings may or may not afford protection to the seed from $\mathrm{X}$-rays. Both varieties and moisture content produced differential reactions.

2. Large seed were more affected by high $X$-ray dosages than were small ones. Larger seed have larger germs, exposing more area to X-ray effects. A decrease of germination and seedling vigor was obtained when large seed were exposed to radiation, although there was no indication of a proportional decrease between germ size and relative damage to seedlings from large and small seed.

3. Germination percentages of oat-seed lots receiving up to $40,000 \mathrm{r}$ of $\mathrm{X}$-rays were as good as those of the checks, when measured on blotters in a plant germinator, but seedling vigor was materially reduced. Lowered germination percentages noted in greenhouse experiments were probably due to insufficient vigor to grow through the soil on the part of many seedlings. Probably all of the X-ray effects at the dosages used were caused by decreases in seedling vigor.

4. Radicals and plumules of the seed were equally damaged by X-ray treatment.

\section{RESUMEN}

En una serie de experimentos diseñados para determinar si la testa de la semilla de avena y el tamaño del embrión afectaban su sensibilidad a radiaciones de rayos $\mathrm{X}$, se obtuvieron los siguientes resultados:

1. La testa puede o no proteger la semilla de los efectos de rayos $\mathrm{X}$. Tanto la variedad como el contenido de humedad de la semilla afectan la naturaleza de la reacción.

2. Las semillas grandes fueron más afectadas por dosis altas de rayos $\mathrm{X}$ que las semillas pequeñas. Como las semillas de mayor tamaño poseen embriones más grandes, por eso exponen mayor área a los efectos de los rayos $\mathrm{X}$. Una reducción en germinación y en vigor vegetativo fué obtenida cuando semillas de mayor tamaño fueron expuestas a radiación. No hubo indicación de reducción proporcional entre el tamaño del embrión y el daño ocasionado a las plantitas obtenidas de semillas grandes y pequeñas.

3. Bajos condiciones controladas en el laboratorio, el porcentaje de germinación de la semilla de avena que recibió hasta 40,000-r de rayos $X$ fué igual al de los testigos. No obstante, el vigor vegetativo se redujo grandemente. La reducción en el porcentaje de germinación observado bajo condiciones de invernadero se debió probablemente al vigor insuficiente de muchas plantitas para crecer a través de la capa de suelo que cubría la semilla. Posiblemente el efecto de las diferentes dosis de rayos $\mathrm{X}$ usados produjo una reducción en el vigor vegetativo de las plantitas. 
4. Las radículas y las plúmulas de las semillas fueron igualmente damnificadas por el tratamiento de rayos $\mathrm{X}$.

\section{LITERATURE CITED}

1. Caldecott, Richard S., Effects of hydration on X-ray sensitivity in Hordeum, Radiation Res. 3 316-30, 1955.

2. Abrams, Raul, Physiologic Effects of X-ray Radiation on Oat Seeds, unpublished M. S. Thesis, Iowa State Library, Ames, Iowa, 1956.

3. Fröier, K., and Gustafsson, A., The influence of seed size and hulls on X-ray susceptibility in cereals, Heredilas 30 583-9, 1941. 